\title{
Engineering and Economic Viability of Using Crushed Construction Waste in the Production of Concrete and Mortar
}

\author{
D.A.T.H. Deiyagala, P.G.N. Priyadarshani, M.A.N. Perera, \\ T.M. Pallewatta, M.N.C. Samarawickrama and D.P.M.B. Tibbatuwawa
}

\begin{abstract}
The main aim of this study was to investigate the suitability of using demolished construction waste (crushed concrete, ceramic tiles and cement blocks) as raw materials in the production of concrete and mortar. Initially, the physical properties of the aggregates made of demolished and crushed concrete, cement blocks and ceramic tiles were tested and the results obtained were compared with the properties of natural aggregates. Secondly, their optimum mix proportions were obtained by conducting a series of tests on the concrete and mortar samples that were produced by partially replacing the natural aggregates in them with demolished aggregates in the proportions of $30 \%, 60 \%$ and $100 \%$ and the results obtained were compared with the results of similar tests carried out on control samples made using only natural aggregates. The results revealed that the physical properties of processed demolished construction materials are almost similar to those of natural aggregates and that the results correlated well with the previous research findings. The results related to the engineering properties indicated that demolished concrete aggregates and crushed coarse tile aggregates can replace natural aggregates up to $30 \%$ and $60 \%$ respectively in the production of Grade 25 concrete. Furthermore, the study revealed that demolished concrete and demolished blocks in the form of fine aggregates can replace sand up to $30 \%$ in proportion in the production of mortar. The direct cost analysis revealed that the use of demolished construction waste material to replace natural aggregates in the production of both concrete and mortar will be profitable only marginally.
\end{abstract}

Keywords: Demolished Concrete Coarse Aggregate (DCCA), Demolished Concrete Fine Aggregate (DCFA), Crushed Tile Coarse Aggregate (CTCA), Demolished Block Fine Aggregate (DBFA), Natural Aggregate (NA), Natural Coarse Aggregate (NCA), Natural Fine Aggregate (NFA), Concrete, Mortar.

\section{Introduction}

The global demand for construction aggregates exceeds 26.8 billion tons per year [2]. In Sri Lanka, there has been a significant increase recently in the use of natural aggregates because of the increased number of infrastructure development projects that are being undertaken. The annual amount of construction and demolished waste produced in Sri Lanka is about 4.0 million tons and the management of that waste has already become an environmental problem [22]. In other developing countries, laws have been introduced to restrict the production of construction and demolished waste through prohibition or through special taxes imposed. The heaviest materials found among construction and demolished waste in Sri Lanka are concrete, blocks (cement and brick), mortar and tile residues of which concrete represents about half of the total waste weight.

The use of mineral aggregates such as broken natural rocks (coarse aggregates) for concrete and river sand (fine aggregate) for both concrete and mortar poses a severe threat to the environment.

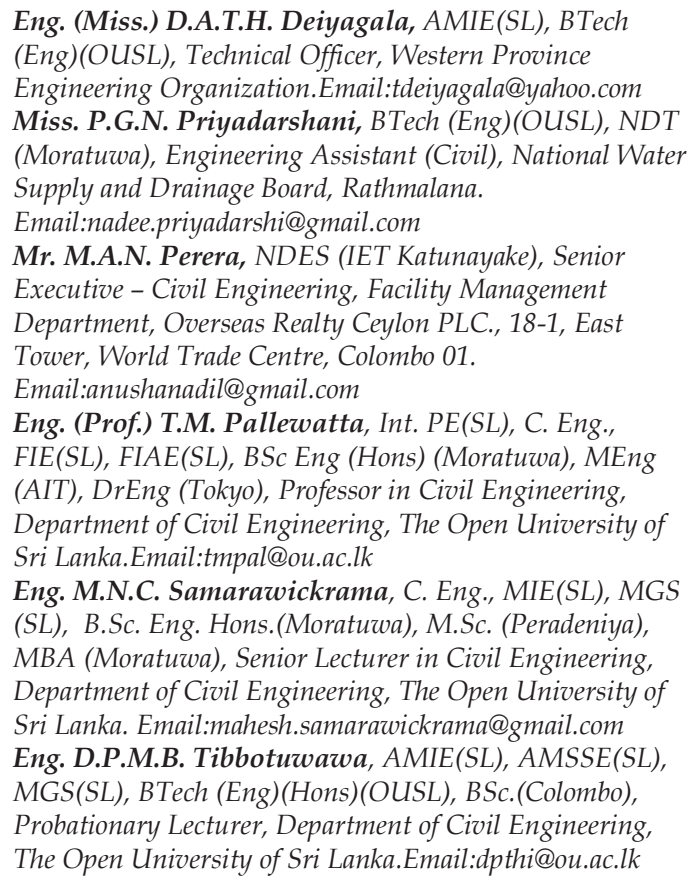


Moreover, the operations associated with aggregate extraction and processing create further damage to the environment. This study becomes timely in this context, in finding a solution to the above mentioned problems. The study was focused on assessing the suitability of using demolished construction waste as alternatives to fine and coarse aggregates in the production of concrete and mortar.

The following were carried out in this regard:

$>$ A comparative study on the physical properties between demolished and crushed construction material and natural aggregates

$>$ Identification of the most appropriate mix proportions of demolished construction material that can replace natural aggregates in concrete and mortar

$>$ A study on the cost effectiveness of producing concrete and mortar using demolished construction materials

\section{Previous Research}

Although the use of demolished construction waste is not still popular in Sri Lanka, internationally, there has already been much research done and applications identified in this regard.

\subsection{Studies done on the use of Demolished Concrete Aggregates (DCAs) in Concrete Production}

Several studies have been carried out in other countries to evaluate the properties of concrete made of recycled concrete aggregates. Their findings have shown that the properties of this concrete will depend on the properties of the recycled aggregates used and on the proportion of fine and coarse natural aggregate content used. Therefore, an in depth study on the properties of the demolished concrete becomes a key necessity.

Generally, crushed concrete aggregates, both coarse and fine, are produced during demolishing and subsequent crushing of concrete.

Monish et al. [17] have successfully used recycled aggregates in the production of concrete. Their investigations have been on assessing the effect of partial replacement of coarse aggregates and fine aggregates with demolished concrete. The test results have shown that the 28 day compressive strength of recycled concrete having up to $30 \%$ of its coarse aggregate replaced with demolished waste is comparable to that of conventional concrete. Also, the 28 day compressive strength of recycled concrete with $10 \%$ of its fine aggregate replaced with demolished waste has been found to be only marginally lower than that of conventional concrete.

Yong \& Teo [30] have revealed that the compressive strength of recycled concrete aggregate is higher than that of normal concrete. However, the split tensile strength, flexural strength and wet density of recycled concrete aggregate were almost same as those of normal concrete. The slump of recycled aggregate concrete has been low but that can be improved by using the recycled aggregate in its saturated condition.

Daniel, [7] has revealed that recycled concrete aggregate could successfully replace natural aggregate completely in both non-structural and structural concrete. He has shown that 28 day compressive strengths of 1:3:6, 1:2:4, 1:1.5:3, 1:1:2 concrete using recycled concrete aggregates were 12.2, 17.1, 21.7 and $25.8 \mathrm{MPa}$ respectively which correspond respectively to a $33 \%, 20 \%, 11 \%$ and $20 \%$ reduction in the compressive strength when compared with that of concrete using natural aggregate. The densities and compressive strengths of natural aggregate concrete were higher than those of recycled aggregate concrete.

Only a limited number of studies have been carried out in Sri Lanka to evaluate the performance of demolished concrete. Kaushalya \& Indrawansha [13] have identified that recycled concrete aggregate could be used as a raw material in the production of concrete. They have shown that the 28 day compressive strength of samples obtained from three different sites and made of 1:2:4 concrete with $100 \%$ recycled concrete aggregates were 19.2, 18.8, 19.0 MPa. According to them, even the concrete with $100 \%$ recycled aggregates was able to attain a compressive strength almost equal to that of standard control samples. Moreover, they were able to further improve the compressive strength of concrete up to 26.7 $\mathrm{MPa}$ by adding plasticizers.

\subsection{Demolished Tile Aggregate (DTA) used in Concrete Production}

Tiles are produced from natural materials sintered at high temperatures. There are no harmful chemicals in tiles. Waste tiles cause only the apparition of pollution and ceramic 
waste can be transformed into a useful course aggregate.

Mashitah et al., [16] have used homogenous ceramic tile waste as a replacement to natural coarse aggregate. They have found that the physical properties of ceramic waste tile aggregates are similar to those of natural coarse aggregates. They have also produced concrete blocks by using ceramic tile waste. However, the strength of these concrete blocks was lower than that control blocks (made of natural aggregates) and was in the range of 41.4 to $48.8 \mathrm{MPa}$.

Tavakoli et al.,[29] have shown that waste tiles can successfully replace both fine and coarse aggregates in concrete. The optimal case was reached when $25 \%$ to $50 \%$ of sand and $10 \%$ to $20 \%$ of coarse aggregate were replaced.

The above results have been further justified by Mertinez et al., [15] by using ceramic waste in structural concrete. The results obtained from the compressive and tensile strength tests have revealed that the compressive strength of concrete increased when a proportion of its natural coarse aggregate was substituted with recycled aggregates.

\subsection{Demolished Concrete Fine Aggregate (DCFA) used in Mortar Production}

Even though various studies on the use of recycled aggregate in concrete have been carried out in the last few years, similar studies on mortar are still at their initial stages. However, it should be noted that some interesting conclusions have been reached through the limited research that has been carried out.

It has been assessed that the performance of mortar that use recycled concrete aggregates is satisfactory [5]. Catarina et al., [5] have replaced natural sand with a fine fraction of demolished concrete fine aggregate (DCFA) keeping the particle size distribution same. Three mortar samples were produced with $20 \%, 50 \%$ and $100 \%$ of demolished concrete fine aggregate along with a reference mortar containing no recycled aggregates. The compressive and flexural strengths, water absorption by capillarity, drying capacity and susceptibility to cracking have been initially tested. Then, based on these results, researchers have been able to select the most satisfactory replacement ratio and determine the properties of the mortar, namely water retentivity, shrinkage, adhesive strength, modulus of elasticity, and water vapour permeability. Surprisingly, outstanding performance has been reported at the initial stage for $20 \%$ and $100 \%$ replacement ratios, leading to a cautious choice of the $20 \%$ ratio at the second stage. Generally, the mortar with a $20 \%$ replacement ratio performed better than the reference mortar, except for adhesive strength and dimensional stability [5].

A research conducted by Fumoto \& Yamada [9] on the influence of the quality of the recycled fine aggregate on the properties of mortar has shown that the compressive strength of mortar decreases and that its average water absorption increases as the amount of its recycled fine aggregate content is increased. They have graded river sand by dividing its particle size into three ranges and have replaced sand of each grade with a recycled fine aggregate which had particles within the same size range. Then, the influence of each range of the recycled fine aggregate on the properties of the recycled mortar had been investigated. The results have shown that when making mortar with the recycled fine aggregates, the particle size has to be kept below $0.6 \mathrm{~mm}$ if they are to have an influence on the properties of the mortar.

Further studies on this aspect have been carried out by Lima et al., [14] and they have examined the mechanical strength, physical properties and drying shrinkage of mortar and compared them with the corresponding properties of mortar made with natural aggregates. Two recycled mortar samples had been made containing $50 \%$ and $100 \%$ of recycled aggregates in place of natural aggregates with a cement/sand ratio of $1: 4$ and 1:8 (by weight) respectively. The results have revealed that the total porosity, absorption rate and drying shrinkage of recycled mortar are higher than those of natural aggregate mortar.

\subsection{Demolished Block Fine Aggregate (DBFA) in Mortar Production}

Very little research has been carried out in the past to ascertain the possibility of using recycled cement blocks. However, a limited number of studies have been carried out on the use of recycled fine aggregate in cement sand blocks. It depicts that the average compressive strength of the blocks that were made of recycled sand (produced after washing with water) has increased by $5.4 \%$ when compared to the compressive strength of the blocks made 
using fresh sand. However, the average compressive strength of the blocks made from recycled sand washed with acetic acid has decreased by $16.3 \%$ of the compressive strength of the blocks made from fresh sand [20].

\section{Methodology}

For sample preparation, demolished concrete, ceramic tiles and demolished block waste were collected from three different sites. Ceramic tile cut pieces generated during the construction of new buildings at several sites were used for the study. The demolished material that was collected was manually broken down into smaller size aggregates through hammer crushing to make their sizes identical to those of natural aggregates. The crushed products were sieved using a $6 \mathrm{~mm}$ mesh size sieve to make Demolished Concrete Coarse Aggregate (DCCA), Demolished Concrete Fine Aggregate (DCFA), Crushed Tile Coarse Aggregate (CTCA), and Demolished Block Fine Aggregate (DBFA) in sufficient quantities to proceed with the study.

In order to compare the physical properties of the above with those of the Natural Aggregates (NAs), Sieve Analysis, Specific Gravity, Bulk Density and Water Absorption Tests were performed in the laboratory. These tests were carried out according to the standard methods described in BS 812, BS 882 and BS 1881.

To study the engineering properties of concrete, slump, unconfined compressive strength, tensile splitting strength, flexural strength and brazilian disc tests were performed according to BS 1881. Batching of concrete was done by weighing the constituent materials based on the adopted mix ratio of 1:1.5: 3. The materials were mixed manually. Two types (DCA and CTCA based) of concrete were produced in the study. DCA based concrete specimens were cast replacing $0 \%$, $30 \%, 60 \%$ and $100 \%$ of the coarse and fine aggregates with DCCA and DCFA respectively. CTCA based concrete specimens were cast replacing $0 \%, 30 \%, 60 \%$ and $100 \%$ of the coarse aggregates by CTCA. The water/cement ratio was such that it produced a slump of $100 \mathrm{~mm} \pm 25 \mathrm{~mm}$ while maintaining the workability of the concrete.

The engineering properties of different mortars were investigated using tests such ason unconfined compressive strength, flexural strength, water absorption and cracking susceptibility conducted according to BS EN 1015. The mortar samples were prepared using ordinary Portland cement, river sand, DCFA and DBFA. The batching of mortar was done by weighing the constituent materials based on the adopted mix ratio of 1:5.

Rock aggregates, $20 \mathrm{~mm}$ in size, were also used in addition to the above mentioned processed demolished/waste aggregates.

A cost analysis was performed for the bestselected replacement ratio of recycled aggregate concrete in mortar. Price rates for this analysis were obtained from construction demolishing contractors and crusher plants and the analysis was performed according to BSR [4] norms. Eventually, the production cost per cube for both concrete and mortar that were made out from processed aggregates were obtained and compared with the costs of similar products made with natural aggregates.

\section{Results and Discussion}

\subsection{Physical Properties of Aggregates}

\subsubsection{Sieve Analysis Test Results for NFA, $D C F A$ and DBFA}

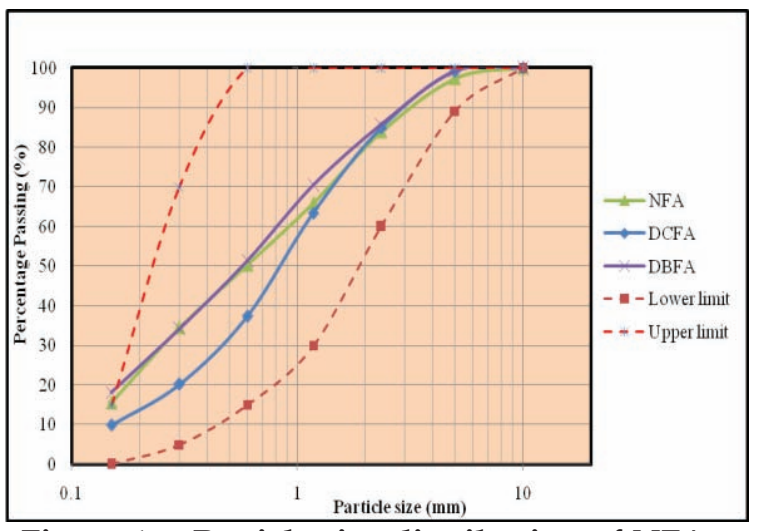

Figure 1 - Particle size distribution of NFA, DCFA and DBFA

The dashed lines of Figure 1 indicate the limits specified in BS 882 for fine aggregates. The particle size distribution of NFA, DCFA and DBFA lies within the BS grading requirements and thus it is confirmed that DCFA and DBFA can replace Natural Fine Aggregates (NFA). 


\subsubsection{Sieve Analysis Test Results for NCA, DCCA and CTCA}

A sample of well- graded aggregate with very few voids will require only small amounts of sand and cement for filling up the voids. The curves of NCA, DCCA and CTCA follow the well-graded curve pattern (Figure 2). Dashed lines indicate the limits mentioned in BS 882 for coarse aggregates. Hence, it is obvious that the particle size distribution of NCA, DCCA and CTCA lie within the BS grading requirements.

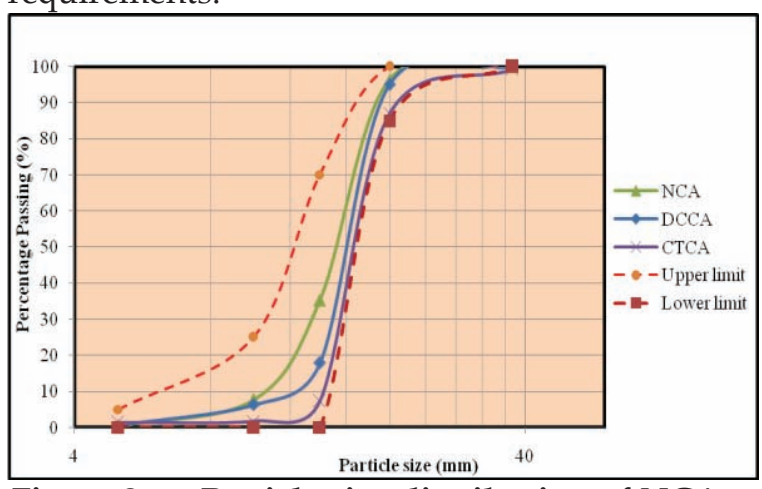

Figure 2 - Particle size distribution of NCA, DCCA and CTCA

\subsubsection{Specific Gravity Test Results}

The results of the specific gravity tests on coarse and fine aggregates are given in Table 1.

Table 1 - Comparison of specific gravity results

\begin{tabular}{|l|l|l|r|}
\hline \multicolumn{2}{|l|}{ Types of Aggregates } & $\begin{array}{l}\text { Specific } \\
\text { Gravity }\end{array}$ & $\begin{array}{l}\text { Variation } \\
\text { with NA }\end{array}$ \\
\hline \multirow{3}{*}{$\begin{array}{l}\text { Coarse } \\
\text { Aggregates }\end{array}$} & NCA & 2.73 & \\
\cline { 2 - 4 } & DCCA & 2.40 & $-12.10 \%$ \\
\cline { 2 - 4 } & CTCA & 2.30 & $-15.75 \%$ \\
\hline \multirow{3}{*}{$\begin{array}{l}\text { Fine } \\
\text { Aggregates }\end{array}$} & NFA & 2.62 & \\
\cline { 2 - 4 } & DCFA & 2.56 & $-2.30 \%$ \\
\cline { 2 - 4 } & DBFA & 2.81 & $+6.80 \%$ \\
\hline
\end{tabular}

These results are compatible with the results reported by Sekar, T., [24].

\subsubsection{Bulk Density Test Results}

The loose bulk densities of DCCA, DCFA, DBFA and CTCA were determined and compared with those of NFA and NCA. Table 2 shows the results of the bulk density tests on the aggregates.

Table 2 - Bulk density test results

\begin{tabular}{|l|l|l|l|}
\hline \multicolumn{2}{|l|}{ Types of Aggregates } & $\begin{array}{l}\text { Loose } \\
\text { Bulk } \\
\text { Density } \\
\left(\mathrm{kg} / \mathrm{m}^{3}\right)\end{array}$ & $\begin{array}{l}\text { Variatio } \\
\text { n with } \\
\text { NA }\end{array}$ \\
\hline $\begin{array}{l}\text { Coarse } \\
\text { Aggregates }\end{array}$ & NCA & 2105.20 & \\
\cline { 2 - 4 } & DCC & 1856.18 & $-11.80 \%$ \\
\hline
\end{tabular}

\begin{tabular}{|l|l|l|r|}
\hline & CTC & 1757.83 & $-16.50 \%$ \\
\hline \multirow{3}{*}{$\begin{array}{l}\text { Fine } \\
\text { Aggregates }\end{array}$} & NFA & 1357.33 & \\
\cline { 2 - 4 } & DCF & 1346.67 & $-0.80 \%$ \\
\cline { 2 - 4 } & DBFA & 1372.00 & $+1.10 \%$ \\
\hline
\end{tabular}

Results for DCCA are higher than the results reported by Gandhi et al., [10] $\left(1660 \mathrm{~kg} / \mathrm{m}^{3}\right)$ and are almost compatible with the values reported by Kaushalya and Indrawaansha, [13].

According to Dhavamani \& Gobinatha [8], the bulk density of CTCA is $1410 \mathrm{~kg} / \mathrm{m}^{3}$ and this value is close to the results of this study. A similar compatibility in results for DCFA and DBFA can be seen in those reported by Akaninyene, [1] and Kaushalya and Indrawaansha, [13].

DCA contains mortar with NA and is light and porous in nature. Therefore, it was obvious that the specific gravity and density of DCA should be lower than those of NA.

\subsubsection{Water Absorption Test Results}

The water absorption characteristics of coarse and fine aggregates were examined and Table 3 illustrates the results.

Table 3 - Water absorption test results

\begin{tabular}{|l|l|c|c|}
\hline \multicolumn{2}{|c|}{ Types of Aggregates } & $\begin{array}{c}\text { Water } \\
\text { Absorption } \\
(\%)\end{array}$ & $\begin{array}{l}\text { Variation } \\
\text { with NA }\end{array}$ \\
\hline \multirow{2}{*}{$\begin{array}{l}\text { Coarse } \\
\text { Aggregates }\end{array}$} & NCA & 3.00 & \\
\cline { 2 - 4 } & DCC & 3.60 & $+20.00 \%$ \\
\cline { 2 - 4 } Fine & CTC & 3.41 & $+13.67 \%$ \\
\hline \multirow{2}{*}{\begin{tabular}{l} 
Aggregates \\
\cline { 2 - 4 }
\end{tabular}} & NFA & 7.18 & \\
\cline { 2 - 4 } & DCF & 8.42 & $+17.27 \%$ \\
\cline { 2 - 4 } & DBFA & 9.50 & $+32.32 \%$ \\
\hline
\end{tabular}

The high volume of water absorbed by old mortar with its original aggregate particles may be the main cause for this variation. The porosity of the adhered mortar allows water to penetrate into accessible pores and this leads to an increase in the water absorption capacity when compared to NA. The higher water absorption observed in CTCA may be due to its surface area, pore structure and clay content as explained by Sudarsana et al., [25]. Relatively higher water absorption rates $(4.8 \%)$ have been reported for CTCA by Tavakoli et al., 2013[29]. Past researchers have reported that the water absorption rates of DCCA are higher than those of NA [26], [30]. Kaushalya and Indrawansha, [13] have reported that water absorption of DCCA and DCFA were 
$7.2 \%$ and $9.0 \%$ respectively. Lima et al, [14] had obtained a water absorption rate of $21 \%$ for DCFA and Akaninyene, [1] has revealed that water absorption rate for crushed sandcrete block is $28.7 \%$ which is around $250 \%$ to $300 \%$ of the values obtained from this study.

According to the above results, it is evident that the physical properties of processed demolished construction material are almost similar to the physical properties of NA and that therefore these materials can be effectively substituted in place of NA.

\subsection{Engineering Properties of Concrete}

\subsubsection{Slump Test Results}

Table 4 - Slump height and water/cement ratio for concrete with varying proportions of NCA and NFA replaced by DCCA and DCFA

\begin{tabular}{|c|c|c|c|c|c|c|c|c|c|}
\hline \multirow{3}{*}{\multicolumn{2}{|c|}{ 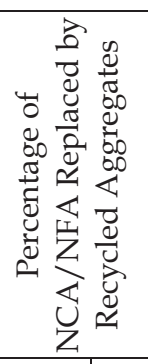 }} & \multicolumn{8}{|c|}{$\begin{array}{c}\text { Percentage of NCA Replaced by } \\
\text { DCCA }\end{array}$} \\
\hline & & \multicolumn{2}{|c|}{$0 \%$} & \multicolumn{2}{|c|}{$30 \%$} & \multicolumn{2}{|c|}{$60 \%$} & \multicolumn{2}{|c|}{$100 \%$} \\
\hline & & $\frac{u}{3}$ & $\begin{array}{l}\text { द्व } \\
\text { है } \\
\text { ह्ञ } \\
\text { के }\end{array}$ & $\begin{array}{c}0 \\
3\end{array}$ & $\begin{array}{l}\text { ह्वे } \\
\text { ह्ञे } \\
\text { के }\end{array}$ & $\frac{u}{3}$ & 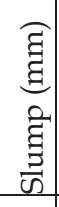 & $\frac{u}{3}$ & 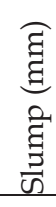 \\
\hline \multirow{4}{*}{ 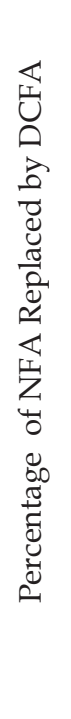 } & @̊ & กี & ิㅡ & 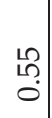 & $\exists$ & $\begin{array}{l}8 \\
0 \\
0\end{array}$ & ิㅗㄱ & $\hat{0}$ & $\stackrel{\infty}{=}$ \\
\hline & ठें & 占 & $\stackrel{\stackrel{ }{ }}{\sim}$ & $\begin{array}{l}: \\
: \\
:\end{array}$ & ปี & $\stackrel{\substack{0 \\
0}}{0}$ & $\stackrel{\infty}{\underset{\sim}{*}}$ & 3ర & $\stackrel{\infty}{\sim}$ \\
\hline & ठ̊ํㅇ & $\begin{array}{l}R \\
\text { R }\end{array}$ & సิ & $\begin{array}{l}\stackrel{R}{2} \\
\stackrel{0}{0}\end{array}$ & $\stackrel{\stackrel{2}{=}}{=}$ & $\begin{array}{l}\stackrel{0}{0} \\
0\end{array}$ & $\stackrel{10}{=}$ & $\begin{array}{l}\hat{~} \\
0\end{array}$ & $\underset{\sim}{\stackrel{一}{~}}$ \\
\hline & $\stackrel{\text { ఠ్ }}{\circ}$ & $\stackrel{\Re}{\stackrel{\Omega}{0}}$ & 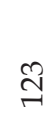 & $\begin{array}{l}\hat{A} \\
0\end{array}$ & $\stackrel{\infty}{\Rightarrow}$ & $\begin{array}{l}\infty \\
\infty \\
0 \\
0\end{array}$ & $\underset{\sim}{8}$ & $\begin{array}{l}\mathscr{\infty} \\
\infty \\
0 \\
0\end{array}$ & $\stackrel{2}{\Omega}$ \\
\hline
\end{tabular}

The amount of water required by concrete increases as DCA /CTCA is introduced to the mixture since DCA and CTCA absorb water from fresh concrete. This would lead to a drier concrete mix and would cause practical problems in moulding. Therefore, a sufficient amount of water had to be added to aggregates to obtain workability and the water/cement ratio recorded. The results of the slump tests are given in Table 4 with an adopted water/cement ratio for NA and DCA (DCCA and DCFA replacing NCA and NFA respectively) based concrete, whilst Table 5 gives slump heights and water/cement ratios for NA and CTCA (only NCA was replaced by CTCA) based concrete.

From Tables 4 and 5, it can be seen that as the amount of recycled aggregates added is increased, the workability of concrete gets reduced proportionately. As explained by Rahman et al, [21], this may be due to the absorption of water by the mortar coating of recycled aggregates making the slump to get reduced, which ultimately will lead to the absorption of a higher water quantity. According to Ridzual et.al, [23], the texture and angular shape of recycled aggregates also has a huge influence on lowering the workability.

Table 5 - Slump height and water/cement ratio for varying proportions of NCA replaced by CTCA

\begin{tabular}{|c|c|c|c|c|c|c|c|}
\hline \multicolumn{8}{|c|}{ Percentage of NCA Replaced by CTCA } \\
\hline \multicolumn{2}{|c|}{$0 \%$} & \multicolumn{2}{|c|}{$30 \%$} & \multicolumn{2}{|c|}{$60 \%$} & \multicolumn{2}{|c|}{$100 \%$} \\
\hline$\frac{v}{3}$ & 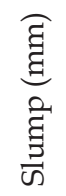 & $\frac{\cup}{3}$ & 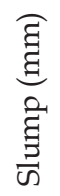 & $\frac{\cup}{3}$ & 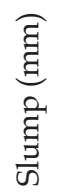 & $\frac{\cup}{3}$ & 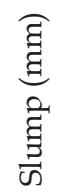 \\
\hline 0.53 & 120 & 0.55 & 118 & 0.58 & 115 & 0.64 & 90 \\
\hline
\end{tabular}

\subsubsection{Compressive Strength Test Results}

The average compressive strength of concrete cubes after 28 days of curing is presented in Table 6 and Table 7.

As can be seen from Table 6 and as can be expected, the NA mix generates the highest compressive strength $\left(30.11 \mathrm{~N} / \mathrm{mm}^{2}\right)$. Furthermore, it can be seen that the compressive strength decreases as the amount of DCA is increased. However, concrete with DCCA and DCFA $\left(\mathrm{P}_{30 / 30}\right)$ replacing NCA and NFA respectively up to $30 \%$ has achieved a compressive strength of $31.45 \mathrm{~N} / \mathrm{mm}^{2}$, which is higher than that obtained when using NA in accordance with BS 5328 . 
Table 6 - Average compressive strength of concrete with varying proportions of NCA and NFA replaced by DCCA and DCFA

\begin{tabular}{|c|c|c|c|c|c|}
\hline \multirow{2}{*}{\multicolumn{2}{|c|}{$\begin{array}{l}\text { Average } \\
\text { Compressive } \\
\text { Strength of } \\
\text { Concrete } \\
\left(\mathrm{N} / \mathrm{mm}^{2}\right)\end{array}$}} & \multicolumn{4}{|c|}{$\%$ of NCA Replaced by DCCA } \\
\hline & & \multirow{2}{*}{$\begin{array}{l}0 \% \\
30.11 \\
\end{array}$} & \multirow{2}{*}{$\begin{array}{l}30 \% \\
23.89 \\
\end{array}$} & \multirow{2}{*}{$\begin{array}{l}60 \% \\
27.22 \\
\end{array}$} & \multirow{2}{*}{$\begin{array}{l}100 \% \\
23.45\end{array}$} \\
\hline$\varangle$ ह & $0 \%$ & & & & \\
\hline$\frac{1}{7} \mathbb{8} \ll$ & $30 \%$ & 29.67 & 31.45 & 27.23 & 26.22 \\
\hline 䒕苛 & $60 \%$ & 24.67 & 20.33 & 21.45 & 19.45 \\
\hline व & $100 \%$ & 23.33 & 23.00 & 21.44 & 17.33 \\
\hline
\end{tabular}

Similar results were reported by Monish et al. [18], with higher values of compressive strength achieved with recycled aggregates (demolished waste coarse aggregates up to $30 \%$ ). Hence, based on this fact, a $30 \%$ replacement ratio of DCCA / DCFA $\left(\mathrm{P}_{30 / 30}\right)$ to NCA was selected as the optimum mix proportion to proceed with the study.

Table 7 - Average compressive strength with varying proportions of NCA replaced by CTCA

\begin{tabular}{|l|l|l|l|l|}
\hline \multicolumn{5}{|c|}{ Percentage of NCA Replaced by CTCA } \\
\hline Average & $0 \%$ & $30 \%$ & $60 \%$ & $100 \%$ \\
\cline { 2 - 5 } $\begin{array}{l}\text { Compressive } \\
\text { Strength } \\
\left(\mathrm{N} / \mathrm{mm}^{2}\right)\end{array}$ & 30.44 & 31.34 & 27.67 & 25.67 \\
\hline
\end{tabular}

According to Table 7, the compressive strength of concrete increases as the amount of NCA replaced by CTCA is increased up to $30 \%$ with further additions decreasing the compressive strength. However, the compressive strength of concrete with $60 \%$ of NCA replaced by CTCA is $27.7 \mathrm{MPa}$ (only 9\% less than the maximum), which is above the BS 5328 requirements. Hence it was reasonable (considering the cost) to select $60 \%$ as the optimum replacement ratio and proceed with the study.

The variation of compressive strength with curing time was investigated for the selected recycled aggregate replacement ratios in respect of DCA, CTCA and NA and the results are shown in Table 8 .
Table 8 - Variation of average compressive strength and density of concrete with curing

\begin{tabular}{|c|c|c|c|c|c|c|}
\hline \multirow[b]{2}{*}{ 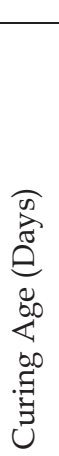 } & \multicolumn{2}{|l|}{ NA } & \multicolumn{2}{|c|}{$\begin{array}{l}\text { DCA based } \\
\text { concrete }\end{array}$} & \multicolumn{2}{|c|}{$\begin{array}{l}\text { CTCA } \\
\text { based } \\
\text { concrete }\end{array}$} \\
\hline & 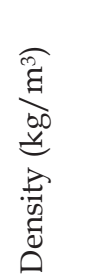 & 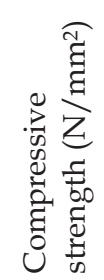 & 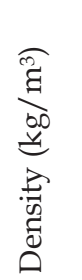 & 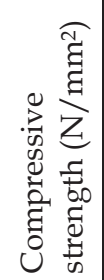 & 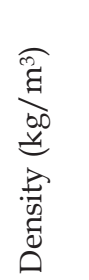 & 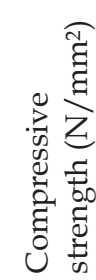 \\
\hline 7 & 2257 & 19.6 & 2247 & 18.2 & 2257 & 19.1 \\
\hline 14 & 2313 & 23.1 & 2258 & 21.8 & 2274 & 22.2 \\
\hline 21 & 2331 & 25.3 & 2327 & 24.4 & 2396 & 27.1 \\
\hline 28 & 2361 & 32.0 & 2350 & 31.1 & 2432 & 29.6 \\
\hline
\end{tabular}

NA has gained $61 \%, 72 \%$ and $79 \%$ of its 28 days maximum compressive strength at 7,14 and 21 days of curing respectively, whilst for DCA it is $58 \%, 70 \%$ and $78 \%$ for the same curing ages. This variation for CTCA based concrete is $65 \%, 75 \%$ and $92 \%$ of its maximum strength at the respective curing ages. The 28 day compressive strength of DCA based concrete was $97 \%$ and CTCA based concrete was $92 \%$ of the 28 day compressive strength of NAC. According to BS 5328, the value of the average compressive strength should not be less than $28 \mathrm{MPa}$ and the compressive strength of an individual cube should not be less than $22 \mathrm{MPa}$. Hence, the results obtained are within the acceptable range of values.

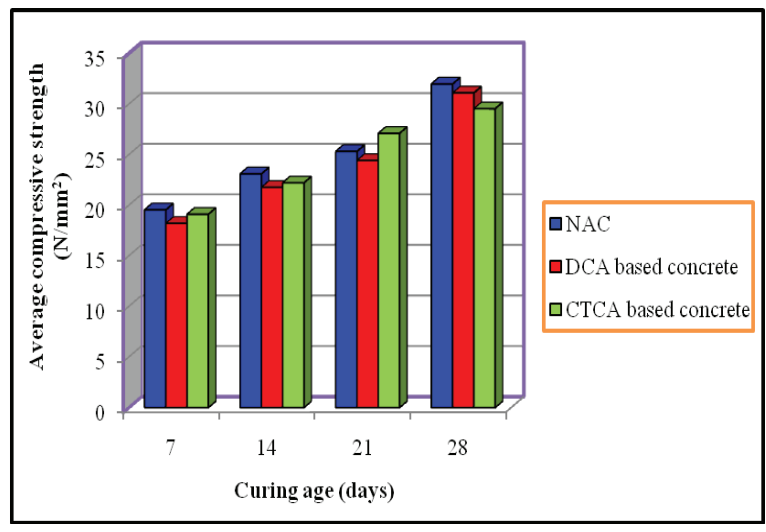

Figure 3 - Variation of average compressive strength of concrete with curing age for different materials

Figure 4 shows a clear relationship between the compressive strength and the density of NA, DCA and CTCA based concrete. When the density of concrete increases, its compressive strength will also increase and the 
densities of DCA and CTCA based concrete were within the corresponding range of NA based concrete.

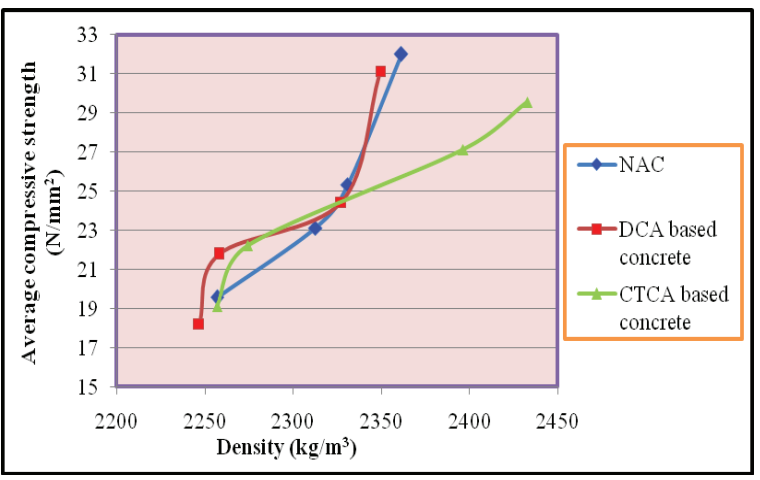

Figure 4 - Relationship between the density and the compressive strength

\subsubsection{Tensile Cylindrical Splitting Strength}

Test Results for NA, DCA and CTCA Based Concrete

Two cylindrical samples, viz., one $150 \mathrm{~mm}$ in diameter and $300 \mathrm{~mm}$ in height and the other $100 \mathrm{~mm}$ in diameter and $200 \mathrm{~mm}$ in height were prepared and their tensile splitting strengths were obtained in accordance with BS 1881 Part 117: 1983 after curing them for 7, 14, 21 , and 28 days. The average tensile splitting strength results obtained for NA, DCA and CTCA based concrete are given in Table 9.

Table 9 - Cylindrical tensile splitting strength of NA, DCA and CTCA based concrete

\begin{tabular}{|c|l|l|l|}
\hline $\begin{array}{l}\text { Curing } \\
\text { Age } \\
\text { (days) }\end{array}$ & $\begin{array}{l}\text { NA Based } \\
\text { Concrete } \\
\left(\mathrm{N} / \mathrm{mm}^{2}\right)\end{array}$ & $\begin{array}{l}\text { DCA } \\
\text { Based } \\
\text { Concrete } \\
\left(\mathrm{N} / \mathrm{mm}^{2}\right)\end{array}$ & $\begin{array}{l}\text { CTCA } \\
\text { Based } \\
\text { Concrete } \\
\left(\mathrm{N} / \mathrm{mm}^{2}\right)\end{array}$ \\
\hline 7 & 1.59 & 1.59 & 1.59 \\
\hline 14 & 1.91 & 1.70 & 1.70 \\
\hline 21 & 2.40 & 2.12 & 1.98 \\
\hline 28 & 2.97 & 2.69 & 2.40 \\
\hline
\end{tabular}

According to the results of the cylindrical tensile splitting strength test, the strength of concrete has increased with curing age. NA based concrete has gained $53 \%, 64 \%$ and $81 \%$ of its 28 day tensile splitting strength at 7,14 and 21 days of curing respectively. DCA based concrete gained $59 \%, 63 \%$ and $79 \%$ of its 28 day tensile splitting strength at 7, 14 and 21 days of curing respectively. CTCA based concrete gained $66 \%, 71 \%$ and $82 \%$ of its 28 day tensile splitting strength at 7, 14 and 21 days of curing respectively. This strength gain pattern is similar for all types of concrete, i.e., NA, DCA and CTCA based concrete. The 28 day tensile splitting strength of DCA based concrete was $91 \%$ of that of NA based concrete and CTCA based concrete $80 \%$. It was also observed that the fracture surface of DCA and CTCA samples contained a high amount of recycled coarse aggregates and that failure planes have passed through the DCA and CTCA particles. Yong \& Teo, [30] have concluded that the cylindrical tensile splitting strength of DCA based concrete is $3.45 \mathrm{MPa}$ for $50 \%$ replacement by recycled aggregates, whilst Kamala \& Rao, [12] have reported that this strength for CTCA based concrete is 2.45 $\mathrm{MPa}$ for $60 \%$ replacement by recycled aggregates. Thus, the above mentioned results firmly tally with the previous findings.

\subsubsection{Flexural Strength Test Results for NA, DCA and CTCA Based Concrete}

Beam specimens of dimensions $500 \mathrm{~mm} \times 100$ $\mathrm{mm} \times 100 \mathrm{~mm}$ were moulded and their flexural strength results were obtained after 28 days of curing, in accordance with BS 1881: Part 118: 1983 .

Kamala \& Rao, [12] state that the flexural strength of CTCA based concrete is 6.54 $\mathrm{N} / \mathrm{mm}^{2}$ for $60 \%$ replacement by recycled aggregates whilst Mashitah et al., [16] state this value as $5.25 \mathrm{~N} / \mathrm{mm}^{2}$ for $60 \%$ replacement by CTCA. Therefore, almost an identical value $\left(6.47 \mathrm{~N} / \mathrm{mm}^{2}\right)$ for flexural strength has been achieved by the CTCA samples with a $60 \%$ replacement ratio .

\section{Table 10 - Flexural strength of NA, DCA and CTCA based concrete}

\begin{tabular}{|l|l|l|l|}
\hline $\begin{array}{l}\text { Type of } \\
\text { Concrete }\end{array}$ & NA & $\begin{array}{l}\text { DCA Based } \\
\text { Concrete }\end{array}$ & $\begin{array}{l}\text { CTCA Based } \\
\text { concrete }\end{array}$ \\
\hline $\begin{array}{l}\text { Flexural } \\
\text { Strength } \\
\left(\mathrm{N} / \mathrm{mm}^{2}\right)\end{array}$ & 7.01 & $\begin{array}{c}5.39 \\
(77 \% \text { of NA) }\end{array}$ & $\begin{array}{c}6.47 \\
(92 \% \text { of NA) }\end{array}$ \\
\hline
\end{tabular}

\subsubsection{Brazilian Disc Tensile Splitting Strength of NA, DCA and CTCA Based Concrete}

Concrete disc samples $150 \mathrm{~mm}$ in diameter and $75 \mathrm{~mm}$ in thickness were moulded and their tensile splitting strengths were measured after 28 days of curing. This test was specifically carried out to assess the behaviour of the tensile strength of concrete made up of CTCA. The results given in Table 11 are encouraging. 
Table 11 - Brazilian disc tensile splitting strength of NA, DCA and CTCA based concrete

\begin{tabular}{|l|l|l|l|}
\hline Type of Concrete & NA & $\begin{array}{l}\text { DCA } \\
\text { Based }\end{array}$ & $\begin{array}{l}\text { CTCA } \\
\text { Based }\end{array}$ \\
\hline $\begin{array}{l}\text { Tensile Splitting } \\
\text { Strength } \\
\left(\mathrm{N} / \mathrm{mm}^{2}\right)\end{array}$ & 2.45 & 2.45 & 2.26 \\
\hline
\end{tabular}

Considering all the above mentioned experimental results, it can be concluded that DCA and CTCA can be effectively used as an alternative construction material in general purpose Grade 25 (1:1.5:3) concrete. Furthermore, DCCA and DCFA can replace NCA and NFA up to $30 \%$ respectively. Moreover, CTCA can potentially replace NCA up to $60 \%$ in Grade 25 general purpose concrete.

\subsection{Engineering Properties of Concrete Mortar}

The results of the compressive strength, flexural strength, water absorption and cracking susceptibility tests are discussed below.

\subsubsection{Compressive Strength Results}

Compressive strength test was performed on $100 \mathrm{~mm} \times 100 \mathrm{~mm} \times 100 \mathrm{~mm}$ sized test cubes after curing them for 28 days. Table 12 shows the average compressive strength of NA, DCFA and DBFA based mortar after 28 days of curing. Increased amounts of DCFA tend to reduce the compressive strength of mortar, whilst the compressive strength of DBFA based mortar shows an increase up to 30\% replacement and a slight decrease at $100 \%$ replacement. This may have been caused by the higher specific gravity of DBFA compared to that of NA, which creates a stronger bond with the cement paste.

Furthermore, the demolished black material may contain some amounts of non-hydrated cement which would complete its hydraulic reaction and settle when in contact with water for the second time, leading to a greater cohesion among the particles and a higher strength. Results reported about DCFA by Neno et al., [19], are similar to those obtained in this study, in which the best compressive strength results have been achieved with a $30 \%$ replacement ratio.
Table 12 - Average compressive strength of NA, DCFA and DBFA based mortar

\begin{tabular}{|c|c|c|}
\hline $\begin{array}{l}\text { Percentage of NA } \\
\text { replaced by DCFA / } \\
\text { DBFA }\end{array}$ & $\begin{array}{l}\text { Average Compressive } \\
\left.\text { Strength (N/ } \mathrm{mm}^{2}\right)\end{array}$ \\
\cline { 2 - 3 } & DCFA & DCBA \\
\hline $0 \%$ & \multicolumn{2}{|c|}{10} \\
\hline $30 \%$ & 9.50 & 10.50 \\
\hline $60 \%$ & 8.50 & 10.30 \\
\hline $100 \%$ & 7.50 & 8.00 \\
\hline
\end{tabular}

\subsubsection{Flexural Strength Test Results}

Flexural Strength Test was performed according to BS 1015-11 to determine the flexural strength of mortar produced with NA, DCFA and DBFA. It was carried out on a prismatic specimen size of $40 \times 40 \times 160 \mathrm{~mm}$ after a curing period of 28 days.

Table 13 - Flexural strength of NA, DCFA and DBFA based mortar

\begin{tabular}{|c|c|c|}
\hline $\begin{array}{l}\text { Percentage of NA } \\
\text { replaced by DCFA / } \\
\text { DBFA }\end{array}$ & \multicolumn{2}{|c|}{$\begin{array}{c}\text { Average Flexural } \\
\text { Strength }\left(\mathrm{N} / \mathrm{mm}^{2}\right)\end{array}$} \\
\cline { 2 - 3 } & DCFA & DCBA \\
\hline $0 \%$ & \multicolumn{2}{|c|}{5.93} \\
\hline $30 \%$ & 4.85 & 5.93 \\
\hline $60 \%$ & 4.77 & 5.66 \\
\hline $100 \%$ & 4.59 & 5.12 \\
\hline
\end{tabular}

As Table 12 and Table 13 depict, flexural and compressive strength values obtained follow a similar pattern.

The maximum flexural strength for both DCFA and DBFA based mortar (as high as when using $100 \%$ NA) was reached at a $30 \%$ replacement ratio and the flexural strength of the mortar started decreasing when more quantities of DCFA and DBFA were added. Identical results have been reported by Neno $e t$ al. [19].

\subsubsection{Water Absorption due to Capillary Action}

The test on water absorption due to capillary action was carried out according to BS 1015-18. Through this test, the increase in the water mass was measured making use of the capillarity of the specimen with a prismatic cross-section, when it is in contact with a water surface. The test was performed on semi prismatic specimens after curing them for 28 days. Water absorption due to capillary action was determined over a period of 10 to 90 minutes as shown in Table 14 for NA and DCFA based mortar. Table 15 shows water absorption due to capillary action over a 
period of 10 to 90 minutes for NA and DBFA based mortar.

Table 14 - Average water absorption of NA and DCFA based mortar

\begin{tabular}{|c|c|c|c|c|c|c|c|c|}
\hline \multirow[b]{2}{*}{ 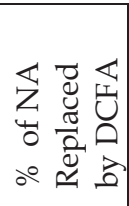 } & \multicolumn{8}{|c|}{ Average Water Absorption (g) } \\
\hline & 青 & 急 & $\begin{array}{l}\text { : } \\
\text { ह్ల }\end{array}$ & $\begin{array}{l}\text { 躳 } \\
\text { 요 }\end{array}$ & 韋 & 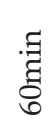 & $\begin{array}{l}\text { శ్ } \\
\text { ప్ర }\end{array}$ & $\begin{array}{l}\text { हू है } \\
\text { वे }\end{array}$ \\
\hline $0 \%$ & $\approx$ & $\begin{array}{l}\text { o̊ } \\
\stackrel{0}{0}\end{array}$ & $\begin{array}{l}0 \\
8 \\
0 \\
0\end{array}$ & ठ্ & $\begin{array}{l}\text { ठे } \\
\text { ○. }\end{array}$ & \begin{tabular}{l}
$\stackrel{2}{0}$ \\
\hdashline
\end{tabular} & $\begin{array}{l}\stackrel{2}{8} \\
\stackrel{0}{\circ}\end{array}$ & $\begin{array}{l}\stackrel{2}{0} \\
0\end{array}$ \\
\hline $30 \%$ & & $\begin{array}{l}\stackrel{\$}{0} \\
\stackrel{0}{\circ}\end{array}$ & $\begin{array}{l}+ \\
8 \\
0 \\
0\end{array}$ & $\begin{array}{l}\stackrel{2}{8} \\
\stackrel{0}{\circ}\end{array}$ & 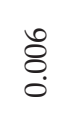 & $\begin{array}{l}\stackrel{8}{\circ} \\
\stackrel{\circ}{0}\end{array}$ & 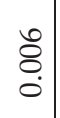 & 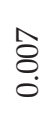 \\
\hline $60 \%$ & & $\begin{array}{l}\stackrel{\Delta}{0} \\
\stackrel{0}{0}\end{array}$ & $\begin{array}{l}\stackrel{8}{ } \\
\vdots \\
0\end{array}$ & $\begin{array}{l}\stackrel{8}{8} \\
\stackrel{0}{0}\end{array}$ & $\begin{array}{l}8 \\
8 \\
0\end{array}$ & $\begin{array}{l}\hat{\sigma} \\
\stackrel{0}{\circ}\end{array}$ & $\begin{array}{l}\text { 今े } \\
\text { ○े }\end{array}$ & 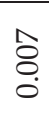 \\
\hline $100 \%$ & & $\begin{array}{l}\qquad 8 \\
0 \\
0 \\
0\end{array}$ & $\begin{array}{l}\hat{\sigma} \\
0 \\
0\end{array}$ & $\begin{array}{l}\hat{\circ} \\
\stackrel{0}{\circ}\end{array}$ & 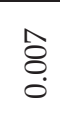 & $\begin{array}{l}\infty \\
\stackrel{0}{0} \\
\stackrel{0}{0}\end{array}$ & $\begin{array}{l}\infty \\
\stackrel{8}{\circ} \\
\stackrel{0}{0}\end{array}$ & ठे \\
\hline
\end{tabular}

Table 15 - Average water absorption of NA and DBFA based mortar

\begin{tabular}{|c|c|c|c|c|c|c|c|c|}
\hline \multirow{2}{*}{ 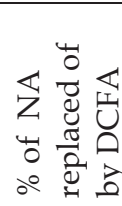 } & \multicolumn{8}{|c|}{ Average Water Absorption (g) } \\
\hline & 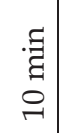 & 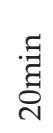 & & $\begin{array}{l}\text { : } \\
\text { ă }\end{array}$ & $\begin{array}{l}\text { हี } \\
\text { ถึ }\end{array}$ & 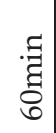 & 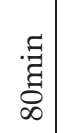 & $\begin{array}{l}\text { वू } \\
\text { वू }\end{array}$ \\
\hline $0 \%$ & 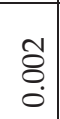 & $\begin{array}{l}8 \\
8 \\
0 \\
0\end{array}$ & & 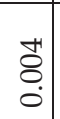 & $\begin{array}{l}+ \\
\stackrel{8}{0} \\
0\end{array}$ & 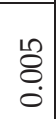 & $\begin{array}{l}\stackrel{2}{\circ} \\
\stackrel{0}{0} \\
\end{array}$ & : \\
\hline $30 \%$ & $\begin{array}{l}0 \\
8 \\
0 \\
0\end{array}$ & $\begin{array}{l}8 \\
8 \\
0 \\
0\end{array}$ & & $\begin{array}{l}\dot{\Xi} \\
8 \\
0\end{array}$ & $\begin{array}{l}+ \\
\stackrel{8}{0} \\
0\end{array}$ & $\begin{array}{l}\stackrel{2}{0} \\
8 \\
0\end{array}$ & $\begin{array}{l}\stackrel{2}{\circ} \\
\stackrel{0}{0}\end{array}$ & $\begin{array}{l}\stackrel{8}{8} \\
\stackrel{0}{0}\end{array}$ \\
\hline $60 \%$ & $\begin{array}{l}\ddot{8} \\
\stackrel{0}{0}\end{array}$ & 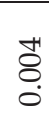 & & $\begin{array}{l}\mathscr{L} \\
8 \\
0 \\
0\end{array}$ & $\begin{array}{l}\stackrel{2}{0} \\
\stackrel{0}{0}\end{array}$ & \&̊. & 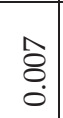 & 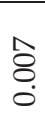 \\
\hline $100 \%$ & $\begin{array}{l}\stackrel{10}{8} \\
0 \\
0\end{array}$ & $\stackrel{\text { L̊ }}{8}$ & $\stackrel{ }{9}$ & $\begin{array}{l}0 \\
8 \\
0\end{array}$ & $\begin{array}{l}0 \\
8 \\
0\end{array}$ & $\stackrel{\hat{\Xi}}{\circ}$ & $\begin{array}{l}\hat{\sigma} \\
\stackrel{0}{0}\end{array}$ & $\begin{array}{l}\stackrel{\infty}{\circ}: \\
\stackrel{0}{\circ}\end{array}$ \\
\hline
\end{tabular}

According to the above tables, the water absorption of mortar has increased when NA was replaced with DBFA and DCFA. This means that the amount of free water in the mixture and the volume of voids would have got reduced. This would have increased the cohesion among particles and would have also decreased the water absorption rate through the capillarity of the prismatic specimen.

Based on laboratory test results of the mortar mentioned above, 30\% replacement by both DCFA and DBFA can be selected as the most appropriate replacement level for the production of 1:5 mortar ( by weight ) mixtures, since both types have shown characteristics significantly similar to that of NA based mortar. Therefore, a 30\% replacement was selected for the Cracking Susceptibility Test.

\subsubsection{Cracking Susceptibility Test}

None of the mortars has shown any type of cracking during the 55 days of observation after 28 days of curing. Therefore, demolished concrete and cement block that were used as the fine aggregate in the mortars have not significantly altered its short/medium term performance through cracking.

\subsection{Cost Effectiveness of Producing Concrete and Mortar Using Demolished Construction Material}

The final objective of this study was to investigate the possibility of introducing a marketable product of composite ready mixed concrete comprising of NA and recycled aggregates. In order to achieve this objective, a cost analysis was carried out to check the cost effectiveness of producing such composite material. In order to achieve economies of scale, a mass scale production system for producing raw material had to be introduced. The following information was gathered from crusher plant operations.

1. Demolished concrete and block material can be crushed easily in all of the selected crusher plants. Therefore, any crushing machinery available in the country will suit this purpose.

2. A manually fed small type crusher plant can be used for crushing ceramic tile waste.

3. Only a small quantity of dust is being generated when crushing demolished waste.

Actual volumetric measurements were taken at the input and output points of the crusher plants when carrying out crushing and subsequent processing of the demolished construction material. The following assumptions were made during the cost analysis based on the bulk density of the fine and coarse aggregates (percentages by weight).

Final product - $62 \%$ of the coarse aggregate, $35 \%$ of the fine aggregate and $3 \%$ of the waste.

$>$ Block waste- $92 \%$ of the fine aggregate and $8 \%$ of the wastage.

D Ceramic tile waste- $98 \%$ of the coarse aggregate and $2 \%$ of the wastage. 
All rates used for this analysis were based on the rates prevailing in the Western Province of Sri Lanka on the date of the analysis.

The production costs of DCCA, DCFA, CTCA and DBFA were calculated and compared with the cost of NA. In addition, the production costs of DCA and CTCA based concrete and DBFA and DCFA based mortar were calculated and compared with NA based concrete and NA based mortar. These results are provided in Table 16 below.

Table 16 - Production Cost Comparison of Concrete and Mortar with NA, DCA,CTCA, DCFA and DBFA

\begin{tabular}{|c|l|l|l|}
\hline \multicolumn{2}{|c|}{ Type } & $\begin{array}{c}\text { Production } \\
\text { Cost (Rs) } \\
\text { per Cube }\end{array}$ & $\begin{array}{c}\text { Cost } \\
\text { Saving } \\
\%\end{array}$ \\
\hline \multirow{2}{*}{$\begin{array}{c}\text { Type of } \\
\text { Coarse } \\
\text { Aggregates }\end{array}$} & NCA & 6500.00 & - \\
\cline { 2 - 4 } & DCCA & 2625.00 & $60 \%$ \\
\hline $\begin{array}{c}\text { Type of } \\
\text { Fine } \\
\text { Aggregates }\end{array}$ & CTCA & 2778.00 & $57 \%$ \\
\cline { 2 - 4 } $\begin{array}{c}\text { Type of } \\
\text { Concrete }\end{array}$ & NFA & 9000.00 & - \\
\cline { 2 - 4 } & $\begin{array}{l}\text { NAFA Based } \\
\text { Concrete }\end{array}$ & 2625.00 & $71 \%$ \\
\cline { 2 - 4 } & $\begin{array}{l}\text { DCA Based } \\
\text { Concrete }\end{array}$ & 3309.00 & $63 \%$ \\
\cline { 2 - 4 } & $\begin{array}{l}\text { CTCA Based } \\
\text { Concrete }\end{array}$ & 35271.00 & - \\
\hline \multirow{2}{*}{$\begin{array}{c}\text { Type of } \\
\text { Mortar }\end{array}$} & $\begin{array}{l}\text { NA Based } \\
\text { Mortar }\end{array}$ & 4788.00 & $5 \%$ \\
\cline { 2 - 4 } & $\begin{array}{l}\text { DCFA Based } \\
\text { Mortar }\end{array}$ & 4596.00 & - \\
\cline { 2 - 4 } & $\begin{array}{l}\text { DBFA Based } \\
\text { Mortar }\end{array}$ & 4617.00 & $4 \%$ \\
\hline
\end{tabular}

As Table 16 depicts, the production of DCCA and CTCA have given $60 \%$ and $57 \%$ cost savings respectively when compared to the cost of production of NCA. The production of DCFA and DBFA have brought about cost savings of $71 \%$ and $63 \%$ respectively when compared to the cost of production of NFA. Both DCA and CTCA based concrete have each made a cost saving of $5 \%$ when compared to NAC. The cost savings obtained from DCFA and DBFA based mortar were 5\% and $4 \%$ respectively when compared to NAM. Considering these figures, it can be concluded that the use of demolished aggregates in the production of general purpose concrete is considerably profitable than when using natural aggregates (Grade 25).
The average costs of ready mixed concrete and DCA and CTCA based concrete are presented in Table 17.

Table 17 - Cost comparison with ready-mixed concrete

\begin{tabular}{|l|l|l|}
\hline Type of Concrete & $\begin{array}{l}\text { Cost per } \mathrm{m}^{3} \\
(\mathrm{Rs})\end{array}$ & $\begin{array}{l}\text { Cost } \\
\text { Saving \% }\end{array}$ \\
\hline $\begin{array}{l}\text { Ready-mixed } \\
\text { Concrete (Average } \\
\text { Value) }\end{array}$ & 14596.00 & - \\
\hline DCA Based Concrete & 12473.00 & $17 \%$ \\
\hline CTCA Based Concrete & 12464.00 & $17 \%$ \\
\hline
\end{tabular}

With regard to the cost of ready-mixed concrete, it is found that the production of DCCA and CTCA based concrete has resulted in a $17 \%$ profit.

In addition to bringing in cost savings, the use of demolished construction waste generates invaluable indirect benefits as well. The use of natural resources is less and there is a reduction of environmental pollution (reduction in the accumulation of construction waste and these are the green benefits of using such material.

\section{Conclusions}

Based on the outcomes of the study, following conclusions can be made.

1. Physical properties such as particle size distribution, specific gravity, bulk density and water absorption in DCCA, DCFA, CTCA and DBFA are almost similar to the corresponding properties of Natural Aggregates. Therefore, the construction waste materials can be used as a substitute to river sand and rock aggregates.

2. The water absorption rate of DCA and CTCA is higher than that of NA. Therefore the workability of DCA and CTCA based concrete is lower than that of NA based concrete. The workability of fresh concrete made of $30 \%$ of DCA and $60 \%$ of CTCA is at a satisfactory level. Therefore, it is highly recommended to use saturated demolished aggregate in the production of concrete and mortar.

3. The compressive strength of DCCA and DCFA based concrete each of which replaced $30 \%$ of coarse and fine aggregates respectively is quite close to the compressive strength of NA based concrete. Furthermore, DCA based 
concrete and NA based concrete have shown a similar variation of density with time.

4. The engineering properties achieved with different mix proportions have revealed that NA can be effectively replaced with DCCA and DCFA up to $30 \%$ each in the production of Grade 25 concrete. Moreover, CTCA can be effectively replaced with NCA up to $60 \%$ in producing concrete of same grade.

5. DCFA and DBFA can be effectively used in preparing 1:5 mortar with a 30\% replacement of sand by DCFA, based on the higher values of its compressive strength, flexural strength and water absorption. Similarly, DBFA can be replaced with sand at a replacement ratio of $30 \%$.

6. According to the cost analysis, the production costs of DCCA, CTCA, DBFA and DCFA in proportions of $60 \%, 57 \%$, $63 \%$ and $71 \%$ respectively are cheaper than those of natural coarse and fine aggregate.

7. The cost analysis further reveals that the concrete mixes of Grade 25 which were made of DCA and CTCA are more economical (5\%) than those with NAC. A similar level of cost saving can be achieved when making 1:5 mortar by using DCFA and DBFA in place of NAM. The cost comparison between the current market prices of ready-mixed concrete and demolished waste concrete reveals that the above cost savings can reach even up to $17 \%$.

In addition, there are several indirect benefits such as the reduction of river sand usage, conservation of natural rock aggregates, and the decrease in the environmental pollution. These benefits can also be taken into account, when recommending DCA, CTCA and DBFA as suitable aggregate materials to replace NA in 1:1.5:3 concrete mixes and 1:5 mortar mixes.

\section{Acknowledgement}

The authors wish to acknowledge the assistance given by the staff of the Department of Civil Engineering, The Open University of Sri Lanka, staff and officials of SD \& CC Concrete Yard and Crusher Plant, Bopitiya, Sanken Lanka Metal Crusher, and
Amithirigala and Priyadarshani Metal Crusher at Mirigama. Special thanks go to the employees working at Globe Hua Khiew Development (Pvt) Ltd for the assistance extended when carrying out crushing.

\section{References}

1. Akaninyene, U., "Recycling Demolition Waste Sandcrete Blocks as Aggregate in Concrete", Journal Faculty of Engineering and Applied Sciences, APRN Vol. 9, September, 2012 pp. 1111-1118.

2. Ashraf, M., Hassam, Z., Magda, E. \& Samir, H., "Recycled Construction and Demolition Concrete Waste as Aggregate for Structural Concrete" Housing and Building National Research Centre Journal, 2013 pp. 193-200.

3. Bakri, M., Hussin, K., Ruzaidi, C., Baharin, S., Ramly, R., \& Khairiatun, N., "Concrete Ceramic Waste Slab", School of Materials Engineering Northern Malaysia University College of Engineering, 2008.

4. Building Schedule of Rates, Offine of Chef Secretary-Western Province, Colombo 07, Sri Lanka, 2010.

5. Catarina, N., Jorge, B. \& Rosario, V., “Using Fine Recycled Concrete Aggregate for Mortar Production" Materials Research, Vol 17, 2014 pp 168-177.

6. Chetna, M., Jayeshkumar, P., "Fly Ash and Recycled Coarse Aggregate in Concrete "International Journal of Engineering Trends and Technology, Vol 4, May, 2013 pp. 1781-1787.

7. Daniel, O., “Compressive Strength of Concrete using Recycled Concrete Aggregate as Complete Replacement of Natural Aggregate" Journal of Faculty of Engineering, Computers $\mathcal{E}$ Applied Sciences, Vol 10, October, 2013 pp. 26-30.

8. Dhavamani, D. \& Gobinatha, D., "Chemical Resistance of Concrete with Ceramic Waste Aggregate", International Journal of Current Engineering and Technology Vol.3, No.3 (August 2013) ISSN 2277 - 4106.

9. Fumota, T. \& Yamada, M., "Influence of Quality of Recycled Fine Aggregate on Properties of Mortar", Mem. Fac, Eng., Ocaka City University, Vol.40, 1999 pp. 81-84.

10. Gandhi, H., Dharshana, B., \& Chetnaban, V., "Study on Use of Recycled Course Aggregate in Concrete", National Conference of Recent Trends in Engineering and Technology, May, 2011. 
11. Hunchate, S., Valikala, G., \& Ghorpade, G., "Influence of Water Absorption of the Ceramic Aggregate on Strength Properties of Ceramic Aggregate Concrete". International Journal of Innovative Research in Science, Engineering and Technology, Vol 11, November, 2013 pp. 63296335.

12. Kamala, R. \& Rao, B., "Reused of Solid Waste from Building Demolition for the Replacement of Natural Aggregate" International Journal of Engineering and Advance Technology, Vol 2(1) 2012 pp 74-76.

13. Kaushalya, P. G. K., \& Indrawaansha, M. W. T. M., "Recycling of Concrete" Final Year Project Thesis, Department of Civil Engineering, The Open University of Sri Lanka, 2008.

14. Lima, P., Lima, M., \& Marins, C., "Drying Shrinkage of Recycled Aggregate Mortar" International Conference on Non Conventional Material and Technology. 2007.

15. Martínez, C., Romero, M., Pozo, J., \& Valdes, A., "Use of Ceramic Wastes in Structurals Concretes" 1st Spanish National Conference on Advances in Materials Recycling and Eco - Energy, 2009 pp. 137-139.

16. Mashitah, D., Kin, C., \& Badorul, A., "Recycling of Homogenous Ceramic Tiles for the Production of Concrete Block" Industrial Cleaner Technology in Practices, 22-23 September, 2008 pp. 60-62.

17. Monish, M., Srivastava, V., Agarwal, V., Mehta, P. \& Kumar, R., "Utilization of Demolished Waste as Fine Aggregate in Concrete" Youth Education and Research Trust, Vol 1, December 2012 pp. 398-400.

18. Monish, M., Srivastava, V., Agarwal, V., Mehta, P. \& Kumar, R., "Demolished Waste as Coarse Aggregate in Concrete" Youth Education and Research Trust, Vol 1, February, 2013 pp. 540542.

19. Neno, C., Brito, J., \& Rosario, V., "Using Fine Recycled Concrete Aggregate for Mortar Production" Materials Research 17(1), 2013 pp. 168-177.

20. Peiris, D., Dissanayake, C., Perera, K., Mallawaarachchi, R., \& Wijesundara, K., "Compressive Strength of Masonry Blocks Made with Recycled Fine Aggregates", SAITM Research Symposium on Engineering Advancements: 2012 pp. 122-124.

21. Rahman, I. \& Hamdam, H., "Assessment of Recycled Aggregate Concrete. Modern Applied Science" , Vol.3, No.10, 2009 pp. 47-54.
22. Ramezden, R., "Construction Sector in Sri Lanka” COWAM seminar, 2006.

23. Ridzual, D., "Early Compressive Strength and Drying Shrinkage of Recycled Aggregate Concrete" Proceedings of Seventh International Conference on Concrete Engineering and Technology, Selangor, Malaysia, June 5-7 2001 pp. 51- 58.

24. Sekar, T., "Studies on Strength Characteristics on Utilization of Waste Materials as Coarse Aggregate in Concrete" International Journal of Engineering Science and Technology, July, 2011 pp. 5436-5440.

25. Sudarsana, R., Giridhar, V., \& Vaishali, G., "Influence of Water Absorption of the Ceramic Aggregate on Strength Properties of Ceramic Aggregate Concrete" International Journal of Innovative Research in Science Engineering and Technology, Vol 2, November, 2013 pp. 63296335.

26. Sudhir, P., Ganesh, S. \& Prashant, D., "Recycled Coarse Aggregates" International Journal of Advanced Technology in Civil Engineering, Vol 2, 2013 pp 2231-5721.

27. Tabak, Y., Kara, M., Gunay, E., Yildirim, S., \& Yilaz, S. "Ceramic Tile Waste as a Waste Management Solution for Concrete", Materials Institute, 2012

28. Takayuki, F. \& Yamada, M., "Influence of Quality of Recycled Fine Aggregate on Properties of Mortar" Research Associate, Vol 40, 1999 pp. 81-84.

29. Tavakoli, D., Heidari, A., \& Karimian, M., "Properties of Concretes Produced with Waste Ceramic Tile Aggregate", Asian Journal of Civil Engineering, Vol 3, 2013 pp. 369-382.

30. Yong, P. \& Teo, D., "Utilization of Recycle Aggregate as Coarse Aggregate in Concrete", UNIMAS E- Journal of Civil Engineering, no 1, August, 2009 pp. 1-6. 